\title{
SOILS OF THE NORTHERN KING COUNTRY
}

\author{
J. D. MCCRAW
}

Professor of Earth Sciences, University of Waikato

\section{Abstract}

The soil pattern of the King Country is dominated by soils developed on volcanic ash. The ash mantle is made up of three broad groups: old ashes (Kauroa Ash and Hamilton Ash); middle age ashes (Rotoehu Ash, Oruanui Ash and Mairoa Ash) and young ash (Taupo Pumice). In the western part of the district the most extensive soils are yellow-brown loams formed on Mairoa Ash; in the eastern part, yellow-brown pumice soils on Taupo Pumice. It is only where erosion has partly or completely removed the ashes from the steeper slopes of the hill country that soils (mainly yellowbrown earths) can form on the underlying greywacke, sandstones and mudstones. Recent soils from alluvium, in association with swamps and peat bogs occur in the valleys of streams and rivers. Although the underlying rocks do not contribute extensively to the soils of the district, they do give rise to characteristic landscapes e.g., greywacke gives steep, narrow valleys and ridges: mudstones give hummocky, slumped slopes; limestones give bluffs, isolated towers, dry valleys and tomos and sandstones and ignimbrites give prominent bluffs.

The soll Pattern of the King Country is dominated by soils developed on volcanic ash. It is only where the ash has been partly or wholly removed by erosion that the underlying rocks can contribute to the parent material of the soils. Even on steep country where erosion has been especially active, there are generally small patches of ash left behind and these contribute to the soils by soil. creep and other slope processes. In the valley bottoms much of the alluvium that makes up the river flats is comprised of volcanic ash washed from the hills.

Although the underlying rocks may play a minor role as parent materials of the soils, they do play a major role in determining the form of the landscape on which the soils lie. For this reason it is worth while to list the sequence of underlying rocks and to note their effect on the landscape.

\section{THE UNDERLYING ROCKS}

The oldest rocks of the district are hard, bluish grey sandstones, argillites and conglomerates generally grouped as "grey- 
wacke". Rocks of this kind form the main mountain ranges of New Zealand. In the King Country they make up the Rangitoto Range to the east and the steep and hilly land to the west. Deep, steep-sided gullies and sharp, narrow ridges, are characteristic of greywacke country. The rock is in demand for road-making chips and concrete 'aggregate but, unfortunately, it is almost everywhere deeply weathered and requires extensive removal of overburden before sound rock is reached.

Where greywacke is soil forming, it gives rise to yellow-brown earths.

Lying on the greywacke are several hundreds of metres of much younger sediments. First are "coal measures" made up of sands and clays containing, here and there, lenses of coal of workable thickness.

Overlying the coal measures is a great thickness of sediments which were laid down under the sea. The sequence begins with mudstone which is rather unstable and prone to landslides and slumping.

Above the mudstone is a thick band of limestone which is of great importance as a source of agricultural limestone but also contributes to our tourist industry because it contains a large number of caves including the renowned Waitomo Caves. Limestone country is easily recognized because of the steep 'bluffs, isolated towers and sinkholes or tomos that are scattered over the landscape. Much of the drainage is underground and surface streams are rare. Soils are rarely developed directly on limestone in this district but where they are, 'they are black, very friable soils classed as rendzinas.

Next are thick mudstones interbedded with sandstones. Again the mudstones are prone to slumping and can be recognized by their gently rolling, hummocky surfaces, whereas the sandstone beds stand out as bluffs - the combination giving a characteris tic, benched landscape. These rocks also form yellow-brown earths where they are soil forming.

Capping the mudstones and sandstones on isolated hills around and immediately west of Te Kuiti, but forming a more continuous cover to the east, is a layer of ignimbrite 'averaging about $100 \mathrm{~m}$ in thickness. This material poured from fissures in the vicinity af Lake Taupo and flowed at high speed over the countryside as a white-hot foam of gas filled with particles of molten rock. When it came to rest it was still sufficiently hot for rock particles to weld into a solid mass of soft but compact, palecoloured rock. Ignimbrites cover thousands of square kilometres 
of the central North Island but those in the King Country- are among the oldest and most far travelled. Modern soils formed from ignimbrite are very rare because the rock is generally exposed only as steep bluffs with characteristic vertical columns. Elsewhere it is covered with volcanic ash.

\section{THE ASH MANTLE}

The King Country, in common with much of the North Island, has been mantled with layer upon layer of volcanic ash erupted spasmodically from a number of vents mainly in the Rotorua and Taupo districts.

The ashes can be grouped into three broad categories - the old ashes, the middle age group and the young ashes.

The oldest ashes belong to the Kauroa 'Ash Formation and the Hamilton Ash Formation. They survive mainly on easy slopes on the low country and are rare on steep or hilly. slopes and on land above $300 \mathrm{~m}$ in altitude where, presumably, they have been removed by erosion. They form a discontinuous mantle, about $3 \mathrm{~m}$ thick, of dark brown 'ashes separated into distinct layers by buried soils. The heavy texture and strongly developed blocky and prismatic structures are evidence of the long period of weathering that these mashes have undergone since they were erupted, perhaps more than 500000 years ago, and serve to distinguish them from the more recent ashes.

The base of the Hamilton Ash Formation is particularly distinctive as it is marked by a thin layer of compact sand that protrudes in a characteristic way from road-side cuttings.

These old ashes are widespread over a large part of the North Island but it is not yet known where they originated. Although they are almost everywhere covered by more recent ashes they form soils in a few places, more commonly towards the west coast. The soils are friable clay loams classed as brown granular loams.

The middle group of ashes are by far the most important soilforming material in the district. They are about $2 \mathrm{~m}$ thick in the east, thin to about $1 \mathrm{~m}$ near Te Kuiti, and then continue with only slight thinning towards the coast.

The lowermost ash, which rests on top of the Hamilton Ash Formation, is Rotoehu Ash. It has a characteristic pale creamy colour and is compact so that it is not unlike a soft sandstone. It was erupted about 42000 years ago from the vicinity of Lake Rotoma near Rotorua. Oruanui Ash is the next distinctive unit. 
It was erupted from near Wairakei about 20000 years ago and forms a pale yellowish-grey band a few centimetres thick that is prominent along road cuttings in the eastern part of the King Country, but from Te Kuiti westwards it is (preserved only here and there. Above the Oruanui Ash is the dark brown, fluffy, very friable ash that forms the soil over most of the district. It was named Mairoa Ash more than 40 years ago but geologists are still not sure where it came from. It was originally 'thought to have been erupted by Mt Egmont or Mt Tongariro and, while this may be true, others think it is a composite ash made up of many thin deposits from the Rotorua district. Soils developed on these 'ashes 'are classed as yellow-brown loams.

The young ashes of the King Country belong to the Taupo Pumice Formation. They are the products of a series of violent eruptions, from vents immediately to the east and north of Lake Taupo, which culminated 1800 years ago. Although it is likely that the whole of the King Country was sprinkled with pumice (small fragments of pumice are found in topsoils almost to the west coast) it is sufficiently thick to act as a soil parent material only east of Te Kuiti. At Benneydale and in the upper Waipa River valley, it is over $30 \mathrm{~cm}$ thick and farther east it increases in thickness until it is nearly one metre thick on the western shores of Lake Taupo. Much pumice was washed into the streams and thick deposits of pumice alluvium occur in the valleys of rivers, such as the Waipa, that have their headwaters in- the eastern part of the district. Soils developed in Taupo Pumice are young and immature and are classed as yellowbrown pumice soils.

\section{THE SOILS}

Although the broad soil pattern of the King Country is fairly simple, a detailed examination reveals a bewildering variety of soils. This is not surprising if it is realized that soils are not simple (bodies but are the complex products of a number of variable environmental factors working in unison. The most variable factor in the King Country is parent material, not because the variety of rocks or ashes is wide but because of the effect of erosioa on the ash mantle. On flat or rolling land the ash mantle is mainly intact and soils are likely to be developed wholly in ash, on hilly or steep land the mantle has been partly or wholly destroyed so that the pattern is a mosaic of soils some are developed wholly in ash, some wholly in underlying 
rock and others on a variety of parent materials with different proportions of ash and rock. Apart from its influence in determining the parent material of soils, topography also influences soil development through its effect on drainage. Soils on flat

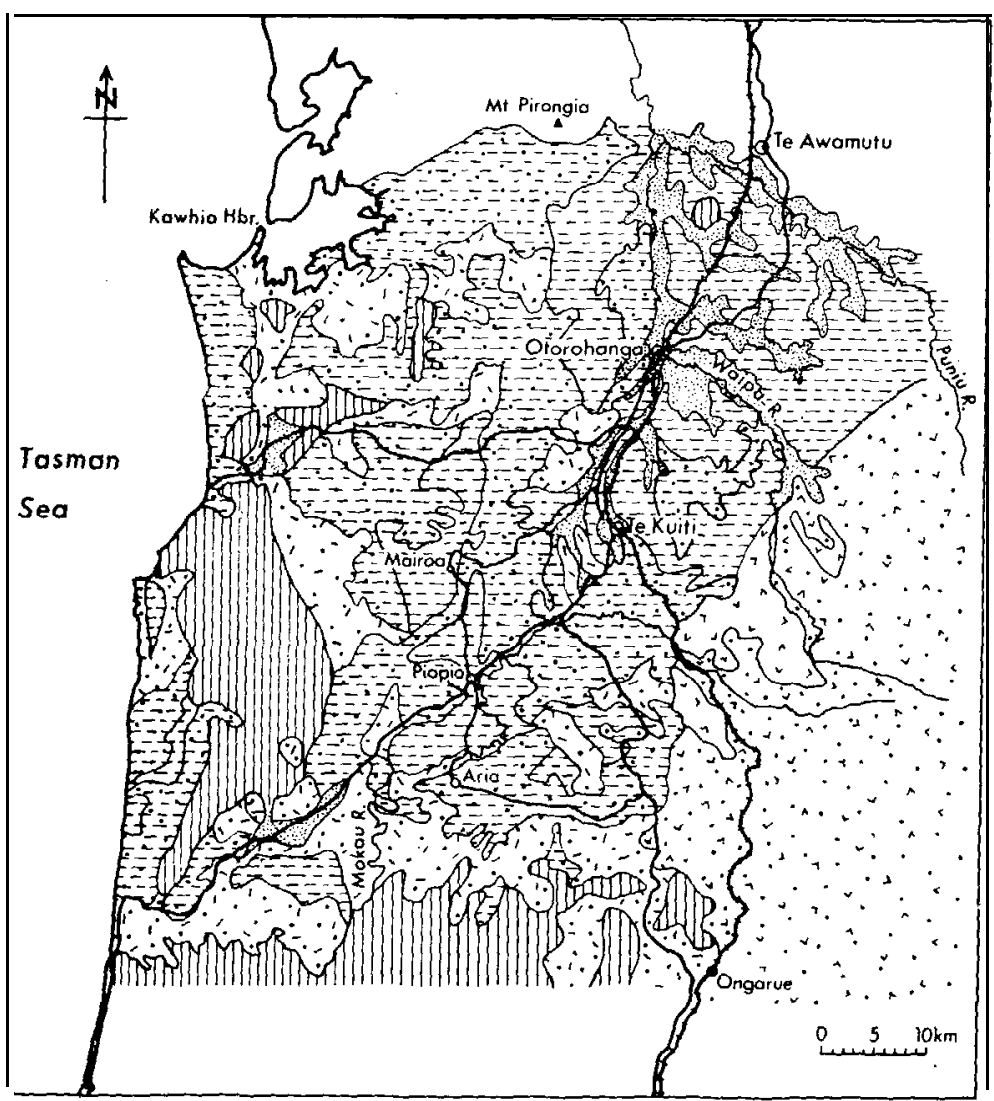

Recent soils from alluvium

(including wet and peoty soils)

Steepland soils

Yellow-brown pumice soils

on flat and rolling land

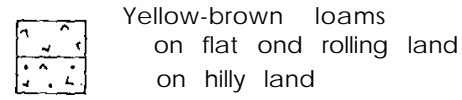

$=0$

- ón hilly land

$$
\text { on hilly land }
$$

Yellow-brown earths
on flat and rolling land
on hilly land

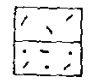

Soils of the northern King Country. (Adapted from Soil Bureau Bulletin No. 5, 1954:) 
land and at the foot of slopes are more likely to be poorly drained than those on slopes.

Climate, too, is important in that soils subject to higher rainfalls, such as those near the west coast or at higher elevations, are more leached of plant nutrients. Vegetation plays a part also in adding to the variety and then, because soils 'are formed by a complex series of chemical and physical reactions which take time, the age of the soil adds yet another variable.

Yellow-brown loams are the most extensive soils in the district. They are developed on Mairoa Ash or on mixed parent material that captains a high proportion of ash. They reach their most extensive development on flat and rolling land but there are patches throughout the hill country. They are generally lacking on steep slopes because the ash has been removed by erosion.

They are distinguished by dark, very friable topsoils and dark yellowish brown, friable subsoils. They are free-draining and hold adequate moisture for pasture growth during summer. Because they are derived from volcanic ash they have a high content of allophane clay, which is formed by the weathering of volcanic glass, and thus have a high fixing capacity for phosphate.

The effect of increasing rainfall is clearly demonstrated by the progressive darkening of both topsoil and subsoil colours from the moderate rainfalls of the north-east to the high rainfalls of the Mairoa district where topsoils are reddish black and subsoils dark reddish brown with thin .iron pans. These leached soils of the uplands require: treatment for cobalt deficiency.

Yellow-brown pumice sails are extensive over the eastern part of the district. The mantle of Taupo Pumice is still reasonably complete on the hill country as well as on easier slopes. The soils are sandy in texture with many pumice lapilli scattered throughout. Because they are young the soils have a low clay content and both topsoil and subsoil structures are weak. Nutrient supply is lower than in yellow-brown loams but where the pumice blanket is thin grass roots can penetrate into older, more fertile materials beneath.

Yellow-brown earths are developed from siliceous sedimentary rocks and are the most widespread and extensive soils in New Zealand but in the King Country are developed only where the ash cover has been eroded and the underlying greywacke, sandstones or mudstones exposed to soil-forming "processes. They are generally confined to steeper slopes where they form a mosaic pattern with patches of yellow-brown loams. 
Yellow-brown earths generally have brownish grey topsoils with firm, nutty structure and yellowish brown subsoils with strongiy developed nntty and blocky structure and, commonly, a prismatic macrostructure. But the properties of individual soils depend largely on their particular parent material. For example, those developed on sandstone 'tend to have sandy clay loam textures whereas those on mudstones range from silt loams to clays. The fertility of yellow-brown earths is moderate but is higher where ash is incorporated in the parent material or where the soils are developed on calcareous mudstones.

Recent Soils from Alluvium include soils on the floors of small stream valleys as well as the soils on the floodplains of the larger rivers. The most extensive areas are in the valleys of the Waipa and Mokau Rivers and their tributaries. Associated with these soils are extensive patches of swamps and peat bogs.

Recent soils have little or no profile development as fresh parent material is added each time they are covered with flood waters. The water table is generally high and the soils are commonly marked by orange coloured mottlings indicating the zone of fluctuating ground-water or their subsoils may be a distinctive bluish-grey colour indicating permanent waterlogging. Most have silty or clay loam textures but in the Waipa River valley there are extensive areas of sandy soils developed on pumice alluvium.

Recent soils are generally fertile but suffer from limitations of high water table, poor drainage and liability to flooding.

Skeletal Soils are those on steep slopes where soil development is limited by constant downhill movement through soil creep and erosion. They occur in small patches throughout the district but 'are more extensive in the south and south-west. Soils are generally shallow with fragments of parent material scattered throughout the profile. Large areas of these 'soils are still covered with bush and it may well be that, taking into account their severe limitations for pastoral use, such as steepness and liability to erosion, they should remain under protection forest. 